\title{
4 Towards a sustainable future of the Indigenous youth
}

\author{
Arctic negotiations on (im)mobility
}

\author{
Reetta Toivanen
}

\section{Introduction: extractivist imaginaries of the Barents Sea region and the local peoples}

Sustainable wellbeing in this chapter means that health, a sufficient standard of living, functioning human relationships, possibilities for self-realization, and the availability of meaningful activities are shared on a relatively equal basis among human beings now and in the future (SYKE 2020). Sustainable wellbeing is also linked to human rights, because without the universal outreach of human rights nothing is sustainable - human rights are at the core in the Sustainability Goals of the United Nations Agenda 2030 (see Toivanen and Cambou forthcoming). Sustainable wellbeing can be theorized through the concept of lived citizenship, as has been proposed by Isin $(2009,2012)$. According to Isin (ibid.), citizenship includes official status and membership in a society, and participation through the existing socio-political structures and practices, but also everyday being and acting in a democratic society. The idea of lived citizenship allows us to analyse the societal actions of Indigenous young people in the Arctic in a more encompassing frame than just as members of one specific society, since experienced and implemented actions exist not only in a given political system, but as everyday actions with peers and family and other social relationships (Kallio et al. 2020).

The question that I wish to tackle in this chapter is whether the decline of young, working-aged people in the Sámi homelands has a detrimental effect on Sámi languages and cultures? Furthermore, I consider a separate question: what is the connection between mobility and sustainable wellbeing? There is a strong assumption that young people living in the circumpolar region, Indigenous or not, need to choose between staying or leaving, and there is no alternative discourse on what (im)mobility might entail. This dilemma is supported by dominant contradictory narratives on the Arctic and its inhabitants.

On the one hand, sustainable development discourses often construct Indigenous peoples as part of nature, fragile and thus in need of support and protection. Consequently, Arctic peoples are imagined as people without their own agency or plans for the future (Toivanen 2019). On the other hand, businesses and state stakeholders portray the Arctic area as a periphery, 
empty of (relevant) peoples and as a place of immense treasures to be exploited and extracted (ibid.). Steinberg et al. (2015) argue that the political tendency to imagine the circumpolar North as empty has been especially pronounced when there has been a strong interest in the local natural resources. In this narrative, the people living in the Arctic region play no role in the future of the area because they are rendered irrelevant. This is visible in the political strategies on the development of the Arctic that often ignore the fact that there are real people living in that area. As an example, Finland is one of the countries that has devised a national strategy to implement UN Agenda 2030, yet it is revealing that the Government Report on the 2030 Agenda for Sustainable Development - Sustainable Development in Finland (Prime Minister's Office 2017) makes no mention of the Sámi Indigenous peoples living in the country. Neither does the document Opportunities for Finland (a joint outlook of the Permanent Secretaries of the ministries on the key questions for the upcoming 2019-2023 government term) (Finnish Government 2019; see also Toivanen and Cambou forthcoming). At the same time, there are again a growing number of plans on how to exploit the Arctic environment for the purposes of national and even global wellbeing (e.g. the building of windmills in Sámi areas, building a railway line through the Sámi homelands; ibid.).

The local populations and Indigenous peoples are not part of the majoritarian narratives on the Arctic region (Ryall et al. 2010; Toivanen 2019). There are signs of politics changing in this regard and the Sámi cannot be totally ignored in development plans. Still, Indigenous ecological knowledge is too seldom included in decision-making in the Arctic (Mustonen and Feodoroff 2018; see also Casi et al. forthcoming).

Many of those who move south to go to secondary school, universities and applied educational institutes stay away permanently and build new lives in the urban centres. They do not, however, as assumed in much of the literature on minorities and language and culture loss, necessarily abandon Sámi culture, languages and lands (Paksuniemi and Keskitalo 2019). Indeed, contrary to the fears of the older generation and expectation of the general narrative, they also remain closely connected to their Sámi lands, their families, cultures and languages (Toivanen and Fabritius 2020). The young Sámi find creative ways to challenge the dominant societal discourses that have for decades predicted the end of Sámi cultures and languages, as will be shown later in this chapter.

This chapter is based on observation and interview materials from the years $2011-2020^{1}$ in three Arctic municipalities in Norway, Finland and Russia. ${ }^{2}$ The interviews were conducted with young people, families and different local stakeholders, such as teachers, local politicians and municipal workers. The interviews and extracts of field notes have been analysed with the Atlas.ti qualitative data analysis and research software program in order to identify the common themes and topics of interest through a discourse analytical lens (Wodak 2015). Using critical discourse analysis, the aim has been to understand how the interviewees construct their being in the world and their views on how societies work (Fairclough 2003, p. 203). 
The research material has been used for several other scientific articles that have focused on wellbeing, solidarity and sustainability. For this chapter, a new approach was taken on the material and what it tells about youth in the Arctic area. I have chosen here to concentrate on the research carried out in Finland, but there are similarities in ways of being young across the Sámi home areas in all of the Sámi homeland, Sápmi. The identified discourses are analysed within the framework of wellbeing, defined as sustainable wellbeing (Kjell 2011), which is enacted through lived citizenship (Isin 2012). Moreover, (im)mobility theories are applied in order to consider what the dichotomy "leaving versus staying" actually tells about youth mobility in the Arctic region.

\section{The European Arctic and its peoples}

The reason for the loss of inhabitants in the area is that the young and people in employment age move away and population concentrates in cities.

(Tennberg et al. 2017, 143)

The Barents region is the most populated area in the Arctic. Also in terms of infrastructure, including roads, electricity and internet networks, the area is well developed. However, during the last two decades, population growth in the Arctic has occurred in Alaska, Iceland, the Canadian Arctic and West Siberia, whilst the Barents region has mostly been experiencing population decline (Emelyanova and Rautio 2016). By January 2015, approximately 5.1 million people permanently resided in the area, a fifth lower than was recorded about two decades ago (6.5 million in 1990; Emelyanova and Rautio 2016, p. 5; Tennberg et al. 2017). The losses were particularly noticeable in the north-west corner of the Russian Federation, whereas in Finnish Lapland, for example, the population had declined only moderately. The northern Norwegian population remained roughly at the same level (Emelyanova and Rautio 2016). In the 1990s, most of the northern regions of Norway, Sweden and Finland - and also throughout the 2000s the Russian North - had slower population growth or faster decline than the rest of their respective countries (Emelyanova and Rautio 2016, p. 5).

One of the peoples traditionally living in the Barents region in the Arctic are the Sámi Indigenous people. The number of Sámi is smaller than that of the majority populations in most of the northern municipalities, and thus they share living space with other local peoples (different minorities and other people who have lived in the territories for several generations) $)^{3}$ and newcomers. According to some estimates, there are approximately 75,000 to 90,000 Sámi people: ca. 40,000 in Norway, 25,000 in Sweden, 11,000 in Finland, and 2,000 in Russia on the Kola peninsula. The Sámi share closely related languages and many cultural features (Kulonen et al. 2005; Pietikäinen 2010). Politically, they have worked together since 1956 in the Sámiráđđi (Sámi Council, earlier Nordic Sámi Council) to strengthen their voices 
vis-à-vis the majority states of Norway, Sweden, Finland (see Toivanen 2003) and, in recent decades, also Russia after a long period of denying the Sámi cultural rights and languages (see Kotljarchuk 2019). Certain occupations have been defined as traditional Sámi livelihoods, such as reindeer herding, fishing, and hunting and gathering (Tennberg et al. 2017, p. 50). Alongside these more traditional professions, there are many new occupations in the fields of tourism and education. Some jobs actually pose a danger for Sámi futures because they negatively impact the environment, such as working in the mining or forest industries.

The fact that the number of people living in the northernmost municipalities of the four countries is declining is a worrisome phenomenon (see also Simakova et al. and Ivanova et al., both in this volume). Because no ethnic statistics are available, the effects of this on Sámi people requires more research (AMAP 2017; see also Tennberg et al. 2017). To explain this trend in terms of Finland, the reasons for young people to leave are rather obvious. First, there is a lack of educational opportunities. There are only three upper secondary schools in the home area of Sámi peoples where it is possible to continue education after comprehensive education. There are five vocational and two higher (one university) educational institutions in Finnish Lapland, but none in the Sámi homeland area. The Sámi Education Institute (SAKK) is the only vocational college in the Sámi home area and its educational opportunities are limited to a few professions. Second, there is a lack of employment opportunities. Thus, finding work is one reason to leave. The unemployment rate can be over $19 \%$ in some municipalities in Lapland, compared to the Finnish average of $7.6 \%$ (Statistics Finland 2020) ${ }^{4}$. There is a strong narrative that if there were better opportunities for education and employment, young people would not need to leave (see e.g., Tennberg et al. 2017) and they would stay instead. But is there necessarily an either/or here, with only two alternatives to choose from? I will argue that being (im)mobile and seeking sustainable wellbeing go hand in hand, leaving space for a multitude of other alternatives then the two opposites.

Based on the current statistics, it is probable that the number of Sámi Indigenous peoples living outside Sápmi-namely, their home territories in all of the four countries in which they reside - continues to increase (Nyseth and Pedersen 2014; Heikkilä et al. 2019). This means that in the whole area of Sápmi, the population is aging rapidly. According to Tennberg et al. (2017, p. 50), this development could be reversed if the young and educated Sámi population were to find employment that matches their education. To achieve this, they emphasize, there is a need to ensure that the traditional livelihoods remain a viable option. The fact that Sámi peoples are moving away from their home territory is not a just a simple act of mobility. Instead, it leads to a negative impact on the general availability of Sámi language instruction in the schools and services in Sámi languages; the less language users, the less language services (Laakso et al. 2016). Furthermore, it also weakens the general right to practice these livelihoods. The rights to practice a traditional livelihood, such as 
reindeer herding, fishing and hunting with traditional traps, are tied to the place of residence (Tennberg et al. 2017, p. 50). This means that when the young people move away from the homelands, they lose their rights to many traditional livelihoods.

Which professions do the young people fill? In Finland in 2020, there were still 4,300 registered reindeer herders, among whom around 900 are under $25 .{ }^{5}$ The high number can partly be explained by the fact that in Sámi families, also children receive their first own reindeer and may appear in the statistics, even though they may not practice herding as a profession. ${ }^{6}$ When looking at the statistics in Finland more closely, however, we can note that despite a decrease in the number of reindeer herders, it is still the profession that has the biggest number of Sámi speakers: 13\% of Sámi speakers worked in a domestic situation involving animal husbandry - almost all with reindeer. ${ }^{7}$ In addition to reindeer herding, there only a few people involved in other livelihoods that are considered traditional Sámi professions. Only a few Sámi fishers are working full-time and none of them are young, according to Statistics Finland. Nor are there professional full-time Sámi hunters or handicraft makers found in Statistics Finland in year 2016. ${ }^{8}$

Agriculture, forestry and fishing today employ $50 \%$ less people than in 1987. In particular, the number of people employed in reindeer herding has diminished significantly. At the same time, the number of people working in social and health services has increased in the last 30 years by over $80 \%$. Also, the number of people working in the field of education and who use Sámi as their mother tongue has increased by $60 \%$ and in the field of public administration by $45 \% .{ }^{9}$ One explanation is the Sámi language law (1086/2003), which both encouraged and enabled the learning of Sámi languages (i.e. in-service training) and provided opportunities to use Sámi languages.

If we still look at the Finnish area of Sápmi, people with a university education make up $23.8 \%$ of the population in Inari, $23.9 \%$ in Sodankylä, $21.3 \%$ in Enontekiö and 26.8\% in Utsjoki (Statistics Finland, 2020). This must be compared with the Finnish average of $41 \%$, and the Organisation for Economic Co-operation and Development (OECD) average of $44 \% .{ }^{10}$ The difference is significant and tells about the problems of highly educated people to find work in Finnish Lapland. Those who are highly educated take positions in schools, kindergartens, administration and media.

\section{Sustainable wellbeing and (im)mobilities}

The youth in the study from the rural regions in the Nordic Arctic will during the next $10-15$ years be engaged in getting an education or establishing as part of the labour market. These young people expect to be mobile and move from their place of origin in order to achieve future dreams. Only a small portion of the participating young people expect to be living in their place of upbringing during the next ten years.

(Karlsdóttir and Jungsberg 2015, 12) 
Above is a citation from a publication that was produced as part of the project Foresight Analysis for Sustainable Regional Development in the Nordic Arctic, commissioned by the Nordic Working Group for Sustainable Regional Development in the Nordic Arctic (see also Karlsdóttir et al. 2017). In a way, it represents a rather hegemonic narrative of Arctic youth who move away from the home territories, voluntarily or not. The emphasis is on youth leaving, and the question of what to do about it dominates the discourse in the existing policy papers and reports.

Quite to the contrary of the citation above, my research material does not support a discourse that presupposes that achieving "future dreams" means necessarily moving and staying away from homelands. The dominant discourse furthermore suggests that remaining in a certain space and placeIndigenous homelands - would be the prerequisite for the healthy and sustainable wellbeing of Indigenous youth. To the contrary, young people in my research seemed to view mobility and wellbeing as going well hand in hand. Being mobile, or changing place, does not in their view mean the abandoning of their Sámi home. For them, the Sámi home is not only a specific area of land but more of a relationship (Keskitalo 2019; see also Virtanen 2012 on Amazonian Indigenous youth).

The term (im)mobility refers to something potentially in between being mobile and not being mobile (Zickgraf 2019). It takes into account the fact that some people may wish to be mobile and move, whereas others with the same sentiments will need to stay because of the multifarious constraints they face. Such constraints include a lack of resources, legal hindrances to obtain visas to other countries, or even personal reasons for not being able to go (Suliman et al. 2019). It also takes into account that some may not be willing to move but are left without any option, for example, due to natural catastrophes that force their movement to a new place (Carling and Schewel 2018). Finally, there are obviously also people who want to stay - and do in fact stay. Thus, (im)mobility is used in this chapter as a term to describe the multifarious aspects of moving or not moving and all the negotiations that may involve.

When it comes to Indigenous youth in the Arctic, there is a strong narrative suggesting that the youth either want to leave or have no option to stay (see Komu and Adams in this volume on their research on Northern culture surrounding migration). As noted above, this is supported by statistical information showing how, over recent decades, the northern municipalities have experienced declines in population. Whereas the demographic information needs to be taken as a given, the question is still whether the decrease of young working-aged people from the Sámi homelands has a detrimental effect on Sámi languages and cultures. What is the connection between mobility and sustainable wellbeing? By definition, sustainable wellbeing is a comprehensive and all-encompassing concept, which requires that the person's whole identity is respected and allowed to be and that it can develop in circumstances that are safe and supporting. Moving or living outside of one's safe "home" would seem to endanger this integrity. 
I try to answer these questions with quotations from my interview material from Finland. Therefore, it is worthwhile mentioning that in Finland there are three language groups of Sámi: Inari, Skolt and Northern Sámi. They have different languages and cultural traditions, but also quite differing experiences of forced assimilation. The situations in Norway and Russia vary in many ways, for example, in respect to educational alternatives and other possible life paths in the Sámi traditional homelands. In Norway, the state attracts university students back to the North with financial support (see Marjomaa 2012). In Russia, there is a lack of workforce and no problem of unemployment (see Stammler and Khlinovskaya 2011 on the Russian Arctic). At the same time, these areas share many similarities, such as the fact that the majority of Sámi live outside the traditional territory and no longer speak a Sámi language.

The following extract from an interview shows how a Sámi who grew up far away from the homeland connects with their Sámi identity.

INTERVIEWER (I): Have you ever thought that you have at some point in your life been, like, that you have not so much thought about being Sámi? Or am I wrong? Or have you always known very strongly that you are a Sámi?

RESPONDENT (R): No. I did not understand it.

I: When did you, so to say, wake up to it or...?

R: Hmm, it was my cousin who at some point asked me to join the City Sámi Association's activities. It was then. But, of course, I had always had that contact to the culture. I have grown up as a child of a Sámi in the capital city region and our culture has travelled with us there. Many of our relatives have moved there, cousin's families and stuff. We kept a lot of contact and Sáminess was also there when we went for holidays to the North. In the North, in Utsjoki and Inari, there we have relatives and so forth. But it was a certain kind of identity awakening when I started being myself active in the City Sámi.

(Interview 041)

This person has grown up in the city. So have many of her relatives, and they have kept in contact with each other in the city. They have also travelled to the North to visit other relatives during holidays. She feels that the Sámi culture has been there all the time, despite the distance to the homeland. At the same time, only after she enacted her Sámi identity through participation in a Sámi association did it really become her conscious identity. As Isin (2009) points out, enacting and participation - the experience of being - bring true belonging. The distance and being mobile did not take away the experience of belonging. But it was, in particular, participation in the City Sámi activities that brought conscious identification as Sámi.

The following extract from another interview shows that young people have no need for an anachronistic understanding of Indigenous culture as something that does not change. 
INTERVIEWER (I): But there is a real outcry that over $70 \%$ of Sámi children are born outside of Sámi home territory.

RESPONDENT (R): But is it true?

$\mathrm{I}$ : It is just [...]

R: Official?

I: Yes, there is study by the Ombud's Office on Minorities, and the Sámi Parliament has a study on it, too.

R: They most probably come. They are estimates [...]

I: [...] over $60 \%$ of Sámi Parliament's voters live outside [the Sámi home territory] [...] and then one thinks that a child who was born in the eastern part of Helsinki and whose mother might have spoken Sámi to her and maybe she received two hours a week of mother-tongue instruction in the school, could that person have a rather eastern Helsinki kind of relationship to reindeer?

R: It may be that way. Exactly that also being Sámi is also changing. It must. Because most probably a person who grew up in Helsinki thinks in a different way than a person who grew up in Angeli village. There is a difference. But there must be a reason that people who grow up in cities do what they have until now done, those who identify with Sámi identity, that they come here [to the home territory] for a while and some even stay forever. Somehow they want to come and the relationship to family is so strong that even though they would live in eastern Helsinki, their grandparents and other relatives are still in their lives.

(Interview 045)

For this person, the question is not where one is born or where one grows up, because it is the relationship with the family that makes that person. Identity is always relational, as Anna Tsing (2007) points out. As the young people tell, it is in these webs of relationships where the Sámi identity is maintained, regardless of place (Casi et al. forthcoming). Living in a city and maintaining a relationship with relatives creates another way of being Sámi. It does not undermine the identity or make it in any way weaker, because that relationship ties the person to the Sámi space. Many of the young people whom I talked to spoke about moving away and coming back and then perhaps moving again (on (im)mobilities that continue, see Zickgraf 2019). For instance, it was for school that one had to move in the first place, since the schools are in village centres or cities. It was quite natural to move and, for many young people, often even a freeing experience to live outside the sight of their parents and relatives. At the same time, the places - the Sámi lands - do not go anywhere. There is no need to fear that they could not return one day if they wanted to. The sustainable wellbeing of the interviewed youth reflects that moving does not entail an interruption of being, but that being mobile always includes the real option of immobility and staying (Zickgraf 2019).

When considering the future of Indigenous cultures and the viability of languages and cultural features, the youth seemed even more optimistic than 
the older generation. Some of the older people were worried that the Sámi who left and went to study and work in the cities would become incapable of continuing the Sámi traditions. Some young people shared these worries as well. Their fears were not only connected to the question of youth mobility, but much more about the larger societal questions of climate change and extractivism in Sámi areas. The following extract serves to illustrate the nature of these fears.

INTERVIEWER: How is this from the Sámi culture point of view? How do you see the connection to reindeer herding? [...] Does the extracting of natural resource threaten the Sámi culture?

RESPONDENT: Yes, it threatens because the reindeer is the cornerstone of Sámi culture. It carries with it from generation to generation knowledge, language that as such contains its own valuable knowledge. And the reindeer has so many dimensions, such as food and handicraft, and then it is such as nature. That I will definitely say, that reindeer herders have a very specific relationship to nature, so different to, for example, some Sámi teacher. And I find it worrisome that our youth can no longer move in the forest. They cannot read the signs of nature. They cannot catch fish. They don't know where reindeer go. That reindeer herding is our last link to nature and how to utilize it in a sustainable manner.

(Interview 008)

Another young person was much more optimistic about the youth's capabilities to maintain and develop Sámi cultures. This following extract illustrates a certain kind of new wave, a pluralistic attitude among some young people, especially those who are involved in the arts.

INTERVIEWER: What do you think, how do different age groups think about the future of Sámi culture?

RESPONDENT: Hmm, it has really been a strong revival in the youth culture. For example, there are new artists that have come up and even on the radio there has been a show for young audiences. It is really great that in this Sámi youth culture the ethos is that all three Sámi languages spoken in Finland and all the three groups are given visibility, and for example on this radio programme all Sámi languages are spoken. It is like, I hope that a certain kind of multicultural Sáminess would become the norm here, that we can and we must even speak all Sámi languages.

(Interview 024)

This person sees Sámi culture as a rich vessel from which new ideas, music and arts grow and that all Sámi groups together can make a real difference in strengthening the culture for the future, regardless of place. For example, the radio is accessible anywhere and it brings all the different Sámi language groups together (on revitalization and radio and social media, see Edygarova 2016). 
Another young person underlined that, whereas there is so much talk about the Sámi cultures disappearing and declining when young people move to cities, he can only see that even very endangered peoples, such as Skolt Sámi, are experiencing a renaissance. This reflects a common feeling throughout the Arctic that young people are optimistic about the future of Sámi cultures and languages, and they see that the new types of social media have come to support the languages' vitality in meaningful ways, such that even people who had earlier abandoned their Sámi identity were eagerly coming back.

INTERVIEWER: How do young people relate-we can now think that you represent that generation-how do young people relate to cultural continuity?

RESPONDENT: In my view, youth think quite positively about it. It has now so much been coming, you know... Skolt Sámi culture has reached such popularity among young people that even people who never ever admitted that they are Skolt Sámi, now they so much want to be Skolt. And the traditional costumes of Skolt Sámi, even those are popular again. Soon everyone wears them, even though there was the time that nobody put them on. And so it is with the Skolt language question, that terribly many language courses have been organized and people are so interested. I don't know why they are, but it is for sure a positive thing that they are.

(Interview 010)

When asked whether the positive attitude of the young is catching on with the older generations, one Sámi woman answered:

Old people are joining and it's kind of the most wonderful of all when you witness that, old people, the elderly, who have seen all this that has happened for decades... Then when you see the children, grandchildren, grand-grandchildren suddenly start to speak Sámi [...] you can't be anything else than pleased.

(Interview 015). ${ }^{11}$

This ongoing urbanization is something that Indigenous locals argue is a cause for concern, and the reason for this worrying development involves the economic and infrastructural changes of modern society. One interviewee stated: "Well, of course, they leave. They have to leave when aiming for higher education, and when they get new jobs there in that place, well, then they stay there" (Interview 039). In this way, leaving is portrayed as forced by the circumstances.

Another interviewee expressed similar concerns when arguing that youth who are active in cultural maintenance are needed, but that even though "many of them would like to stay here in their region of birth" [...] "the young will leave, they leave for daily bread, they have to!" (Interview 006). In this way, Sámi culture is constructed as intrinsically bound up with the Sámi 
homelands, with youth leaving as forced and a threat to Sámi culture being sustained.

Whereas young people do not consider leaving as an act that separates them from Sámi culture, the concept of land is very strong for many Indigenous youth. This relationship does not seem to become weakened, even for those who have chosen or felt forced to move from their place of birth in the North. One young Sámi woman explained in an explicit way what was witnessed during the fieldwork:

But like, for me it's really important, I have moved an insane amount of times. And still I know that when I go to [my home village] and I put my hand on the land, then I know that this is it, there my home is. It's really important for me to have that place, where I know that there they have watched the landscapes a hundred years ago, there they watched them two hundred years ago, there they watched the landscapes a thousand years ago. It is really important. Like, I define Sáminess through, like the same what it means to be Indigenous. It is the same as being Sámi. It is what is important to me, what I hold valuable, what my values are, what my worldview is. Through that my Sáminess is built. It's not built from anything else. And from that I know where the roots are from which I have been raised.

(Interview 040)

This person was born and raised in her early years in Sápmi, and the connection remains very strong despite the fact that she has moved so many timesand even though she may not end up living her life in the village and on the land that she connects with so strongly. Feeling a strong connection to the homeland, she does not experience leaving as a definitive abandonment of Sámi culture.

Many envision themselves as still living in their place of birth but simultaneously commuting to work in some urban area, or living in an urban area but frequently visiting their homeland and maintaining ties through social media, as well as a strong place identity connected to the traditional land. Social media, distant learning, easy travelling and different cultural festivals in the various countries are supporting young people's connection to Sámi languages and the formation of shared Indigenous identities. In scholarly attempts to decolonize notions of place, similar observations have been made among Indigenous urban youth in other places as well (see Virtanen 2012 on Amazonian youth and Greenop 2009 on Indigenous youth in Queensland, Australia). Relationships replace the concrete concept of land as the basis for identity.

\section{Conclusions: (im)mobility allowing for sustainable futures}

I began this chapter by stating that there is a strong narrative that if the young people living in the Indigenous Sápmi territories were to have better 
opportunities for education and employment, they would not need to leave. The other strong narrative is that when they leave, they endanger the sustainability of Sámi languages and culture (and livelihoods). I asked whether the mobility of young people leads to erosion of Sámi languages and culture and if there is necessarily an either/or of two alternatives to choose from? I analysed my research materials and arrived at another conclusion, that being (im) mobile and seeking sustainable wellbeing can go hand in hand. There is enough space in young peoples' lives for a multitude of other alternatives then the two opposites. Thus, binary thinking - which, according to Siraj and Bal $(2017,398)$, "counterpoises mobility and immobility as two antagonistic concepts" - does not seem to apply to young Sámi. Instead, I argue that mobility and immobility are intrinsically related and their relationship is asymmetrical.

Recent research has shown that young people find new, creative ways of voicing and experiencing Sámi identity (Mathisen et al. 2017; Toivanen and Fabritius 2020; Joona and Keskitalo, this volume). They are fluent in expanding its discursive and geographical reach, thereby transcending the restrictive dichotomies of nature and culture, tradition and modernity, and centre and periphery.

I believe that it is important, as Wiegel et al. (2019) argue, to develop a grounded understanding of the diverse ways in which people cope with migration pressures (as well as educational pressures, desires for employment, or environmental change). This means that in addition to people's capacities for (im)mobilities, we also need to study their desires to engage in particular (im)mobility practices. What I mean here is that (im)mobility practices, real or imagined, involve young people, especially young women, moving from Lapland to southern cities, so that the Sámi culture and languages get lost. According to Nyseth and Pedersen (2014), it is precisely the moving to urban areas that has been a symbol of assimilation, cultural loss and losing one's roots. My study indicates that the young people of today's generation do not want to engage in (im)mobility practices that would cut their roots and souls from their Indigenous identities. They locate Sáminess in the relational webs around them, independent of the place where they reside.

\section{Notes}

1 This chapter was mainly funded by the Academy of Finland; see the acknowledgements section.

2 The interviews (ca. 260) are all transliterated, coded and anonymized. The interviewed were mostly carried out in the majority languages of the respective countries.

3 The question of who is Sámi is full of political tensions in Finland but not in other countries. See Heinämäki et al. 2017.

4 This contrasts with the Russian Arctic, where there is a shortage of labor, and yet people still leave, see Ivanova et al. and Bolotova, both in this volume.

$5 \mathrm{https} / /$ paliskunnat.fi/poro/poronhoito/poromiehen-ammatti/poronuoret/

$6 \mathrm{https} / / /$ paliskunnat.fi/py/materiaalit/tilastot/poronomistajat and https://paliskunnat.fi/poro/poronhoito/poromiehen-ammatti/poronuoret/. 
7 In Finland, the reindeer counts as a domestic animal — even though in the Sámi home area it mostly lives in freedom.

8 c, https://www.tilastokeskus.fi/tietotrendit/blogit/2019/hyvaa-saamelaistenkansallispaivaa/).

9 Ibid, fn. 7.

10 Valtioneuvosto 2019, https://valtioneuvosto.fi/-//1410845/oecd-vertailusuomessa-kilpailu-korkeakoulupaikoista-on-kovaa.

11 There are also many older people who rejected their own Sámi identity due to the strong assimilation policies and practices and who cannot understand why their children or grandchildren would voluntarily subscribe to a minority identity (see, e.g., Toivanen and Fabritius 2020; Sarivaara 2016; Grenoble and Whaley 1998).

\section{References}

AMAP (2017) Adaptation actions for a changing Arctic: Perspectives from the Barents Area. Oslo: Arctic Monitoring and Assessment Programme (AMAP). Available at: https://www.amap.no/documents/download/2981/inline.

Bolotova, A. (this volume) 'Leaving or Staying? Youth Agency and the Livability of Industrial Towns in the Russian Arctic', in Stammler, F. and Toivanen, R. (eds) Young people, wellbeing and placemaking in the Arctic. London: Routledge, pp. 53-76.

Carling, J. and Schewel, K. (2018) 'Revisiting aspiration and ability in international migration', Journal of Ethnic and Migration Studies, 44(6), pp. 945-963. doi: 10.1080/1369183X.2017.1384146.

Casi, C., Guttorm, H. and Virtanen, P. K. (forthcoming) 'Traditional ecological knowledge', in Krieg, C. P. and Toivanen, R. (eds.) Situating sustainability: A handbook of contexts and concepts. Helsinki: Helsinki University Press, pp. 202-216.

Edygarova, S. (2016) 'Standard language ideology and minority languages: The case of the permian languages', in Toivanen, R. and Saarikivi, J. (eds.) Linguistic genocide or superdiversity? New and old language diversities. Series on linguistic diversity and language rights. Blue Ridge Summit, PA: Multilingual Matters, pp. 326-352. doi: $10.21832 / 9781783096060$.

Emelyanova, A. and Rautio, A. (2016) 'Population diversification in demographics, health, and living environments: The Barents Region in review', Nordia Geographical Publications, 45(2), pp. 3-18. Available at: https://nordia.journal.fi/article/view/ 64852.

Fairclough, N. (2003) Analyzing discourse: Textual analysis for social research. London: Routledge.

Finnish Government (2019) Opportunities for Finland. Publications of the Finnish Government 2019, 3 Available at: http://urn.fi/URN:ISBN:978-952-287-694-2.

Greenop, K. (2009) 'Place meaning, attachment and identity in contemporary Indigenous Inala, Queensland'. Conference paper at Perspectives on urban life: Connections and reconnections, 28 September-2 October 2009, Australian National University, Australian Institute of Aboriginal and Torres Strait Islander Studies, Canberra.

Grenoble, L. and Whaley, L. (1998) Endangered languages: Language loss and community response. Cambridge: Cambridge University Press.

Heikkilä, L., Laiti-Hedemäki, E. and Miettunen, T. (2019) Buorre eallin gávpogis: saamelaisten hyvä elämä ja hyvinvointipalvelut kaupungissa [Good life of Sámi and wellbeing services in the city]. Rovaniemi: Lapin Yliopisto.

Heinämäki, L., Allard, C., Kirchner, S., Xanthaki, A., Valkonen, S., Mörkenstam, U., Bankes, N., Ruru, J., Gilbert, J., Selle, P., Simpson, A. and Olsén, L. (2017) 
Saamelaisten oikeuksien toteutuminen: kansainvälinen oikeusvertaileva tutkimus. [Actualizing Sámi Rights: International Comparative Research] Helsinki: Valtioneuvoston kanslia (Valtioneuvoston selvitys- ja tutkimustoiminnan julkaisusarja, nro 4/2017).

Isin, E. F. (2009) 'Citizenship in the flux: The figure of the activist citizen', Subjectivity, 29(1), pp. 367-388. doi: 10.1057/sub.2009.25.

Isin, E. F. (2012) Citizens without frontiers. New York and London: Bloomsbury Publishing Plc.

Ivanova, A., Oglezneva, T. and Stammler, F. (this volume) 'Youth law, policies and their implementation in the Russian Arctic', in Stammler, F. and Toivanen, R. (eds) Young people, wellbeing and placemaking in the Arctic. London: Routledge, pp. 147-169.

Joona, T. and Keskitalo, P. (this volume) 'Youths' and their guardians' prospects of reindeer husbandry in Finland', in Stammler, F. and Toivanen, R. (eds) Young people, wellbeing and placemaking in the Arctic. London: Routledge, pp. 93-119.

Kallio, K. P., Wood, B. E. and Häkli, J. (2020) 'Lived citizenship: conceptualising an emerging field', Citizenship Studies, 24(6), pp. 713-729. doi: 10.1080/ 13621025.2020.1739227.

Karlsdóttir, A. and Jungsberg, L. (2015) Nordic Arctic youth future perspectives. Stockholm: Nordregio.

Karlsdóttir, A., Olsen, L. S., Harbo, L. G., Jungsberg, L. and Rasmussen, R. O. (2017) 'Future regional development policy for the Nordic Arctic: Foresight analysis 2013-2016', Nordregio Report 2017, p. 1. Available at: http://norden.diva-portal. org/smash/get/diva2:1069494/FULLTEXT01.pdf (Accessed January 2021).

Keskitalo, P. (2019) 'Nomadic narratives of Sámi people's migration in historic and modern times', in Uusiautti, S. and Yeasmin, N. (eds.) Human migration in the Arctic. Singapore:Palgrave Macmillan,pp.31-65.doi:10.1007/978-981-13-6561-4_3.

Kjell, O. N. E. (2011) 'Sustainable well-being: A potential synergy between sustainability and well-being research', Review of General Psychology, 15(3), pp. 255-266. doi: $10.1037 / \mathrm{a} 0024603$.

Komu, T. and Adams, R.-M. (this volume) "Not wanting to be "stuck": Exploring the role of mobility for young people's wellbeing in northern Finland', in Stammler, F. and Toivanen, R. (eds) Young people, wellbeing and placemaking in the Arctic. London: Routledge, pp. 32-52.

Kotljarchuk, A. (2019) 'Indigenous people, vulnerability and the security dilemma: Sami school education on the Kola Peninsula, 1917-1991', in Kortekangas, O., Keskitalo, P., Nyyssönen, J., Kotljarchuk, A., Paksuniemi, M. and Sjögren, D. (eds.) Sámi educational history in a comparative international perspective. Cham: Palgrave Macmillan, pp. 63-82.

Kulonen, U.-M., Seurujärvi-Kari, I. and Pulkkinen, R. H. (2005) The Saami: A cultural encyclopaedia. Helsinki: Suomalaisen Kirjallisuuden Seura (Suomalaisen Kirjallisuuden Seuran toimituksia, no. 925).

Laakso, J., Sarhimaa, A., Spiliopoulou Åkermark, S. and Toivanen, R. (2016) Towards openly multilingual policies and practices. Assessing minority language maintenance across Europe. Bristol: Multilingual Matters.

Marjomaa, M. (2012) 'North Sámi in Norway: An overview of a language in context', Working papers in European Language Diversity, 17. Available at: https://www.oulu. fi/sites/default/files/content/Giellagas_Marjomaa_NorthSamiInNorway.pdf.

Mathisen, L., Carlsson, E. and Sletterød, N. A. (2017) 'Sámi identity and visions of preferred futures: Experiences among youth in Finnmark and Trøndelag, Norway', The Northern Review, 45, pp. 113-139. doi: 10.22584/nr45.2017.007. 
Mustonen, T. and Feodoroff, P. (with the Skolt Sámi Fishermen of Sevettijärvi) (2018) 'Skolt Sámi and Atlantic Salmon Collaborative Management of Näätämö Watershed, Finland as a case of Indigenous evaluation and knowledge in the Eurasian Arctic', Indigenous Evaluation - New Directions for Evaluation, 159, pp. 107-119. doi: 10.1002/ev.20334.

Nyseth, T. and Pedersen, P. (2014) 'Urban Sámi identities in Scandinavia: Hybridities, ambivalences and cultural innovation', Acta Borealia, 31(2), pp. 131-151. doi: 10.1080/08003831.2014.967976.

Paksuniemi, M. and Keskitalo, P. (2019) 'Christian morality and enlightenment to the natural child: Third-sector education in a children's home in Northern Finland (1907-1947)', in Kortekangas, O., Keskitalo, P., Nyyssönen, J., Kotljarchuk, A., Paksuniemi, M. and Sjögren, D. (eds.) Sámi Educational History in a Comparative International Perspective. Cham: Palgrave Macmillan, pp. 161-185. doi: 10.1007/978-3-030-24112-4_10.

Pietikäinen, S. (2010) 'Sámi language mobility: scales and discourses of multilingualism in a polycentric environment', International Journal of the Sociology of Language, 2010(202), pp. 79-101. doi: 10.1515/ijs1.2010.015.

Prime Minister's Office (2017) Prime Minister's office government report on the 2030 agenda for sustainable development - Sustainable development in Finland - Longterm, coherent and inclusive action. Helsinki: Prime Minister's Office Publications $(11 / 2017)$.

Ryall, A., Schimanski, J. and Wærp, H. H. (2010) 'Arctic Discourses: An introduction', in Ryall, A., Schimanski, J. and Wærp, H. H. (eds) Arctic Discourses. Cambridge: Cambridge Scholars Publishing, pp. ix-xxiii.

Sarivaara, E. (2016) Emergent Sámi identities - From assimilation towards revitalization, in Toivanen, R. and Saarikivi, J. (eds.) Linguistic genocide or superdiversity? New and old language diversities. Bristol: Multilingual Matters, pp. 357-404.

Simakova, A., Pitukhina, M. and Ivanova, A. (this volume) 'Motives for migrating among youth in Russian Arctic industrial towns', in Stammler, F. and Toivanen, R. (eds) Young people, wellbeing and placemaking in the Arctic. London: Routledge, pp. 17-31.

Siraj, N. and Bal, E. (2017) 'Hunger has brought us into this jungle: Understanding mobility and immobility of Bengali immigrants in the Chittagong Hills of Bangladesh', Social Identities, 23(4), pp. 396-412. doi: 10.1080/13504630.2017. 1281443.

Stammler, F. and Khlinovskaya, E. (2011) 'Einmal Erde und zurück: Bevölkerungsbewegungen in Russland's hohem Norden', Osteuropa, 61(2-3/2011), pp. 347-369. Availabe at: http://www.zeitschrift-osteuropa.de/hefte/2011/2-3/ einmal-erde-und-zurueck/.

Statistics Finland (2019) Municipal Key figures 2019. Available at: https://pxnet2.stat. fi/PXWeb/pxweb/en/Kuntien_avainluvut/.

Statistics Finland (2020) Työvoimatutkimus 2020. Available at: http://www.stat.fi/til/ tyti/2020/12.

Steinberg, P. E., Tasch, J. and Gerhardt, H. (2015) Contesting the Arctic: Politics and imaginaries in the circumpolar North. London: I.B. Tauris.

Suliman, S., Farbotko, C., Ransan-Cooper, H., McNamara, K. E., Thornton, F., McMichael, C. and Kitara, T. (2019) 'Indigenous (im)mobilities in the Anthropocene', Mobilities, 14(3), pp. 1-21. doi: 10.1080/17450101.2019.1601828.

SYKE (2020) Suomi ja kestävä hyvinvointi. Available at: https://www.syke.fi/fi-FI/ Suomi_ja_kestava_hyvinvointi. 


\section{Reetta Toivanen}

Tennberg, M., Emelyanova, A., Eriksen, H., Haapala, J., Hannukkala, A., J.K. Jaakkola, J., Jouttijärvi, T., Jylhä, K., Kauppi, S., Kietäväinen, A., Korhonen, H., Korhonen, M., Luomaranta, A., Magga, R., Mettiäinen, I., Näkkäläjärvi, K., Pilli-Sihvola, K., Rautio, A., Rautio, P., Silvo, K., Soppela, P., Turunen, M., Tuulentie, S. and Vihma, T. (2017) The Barents area changes - How will Finland adapt? [Barentsin alue muuttuu-miten Suomi sopeutuu?]. Helsinki: Valtioneuvoston kanslia (Valtioneuvoston selvitys- ja tutkimustoiminnanjulkaisusarja, nro 31/2017). Available at: http://pure.iiasa.ac.at/id/eprint/14469/1/The\%20Barents $\% 20$ area $\% 20$ changes.pdf.

Toivanen, R. (2003) 'Saami people and the Nordic civil societies', in Götz, N. and Heckmann, J. (eds.) Civil society in the Baltic Sea Region. Aldershot: Ashgate, pp. 205-216.

Toivanen, R. (2019) 'European fantasy of the Arctic region and the rise of Indigenous Sámi voices in the global arena', in Sellheim, N., Zaika, Y. V. and Kelman, I. (eds.) Arctic triumph: Northern innovation and persistence. New York: Springer International Publishing, pp. 23-40.

Toivanen, R. and Cambou, D. (forthcoming) 'Human rights', in Krieg, C. P. and Toivanen, R. (eds.) Situating sustainability: A handbook of contexts and concepts. Helsinki: Helsinki University Press.

Toivanen, R. and Fabritius, N. (2020) 'Arctic youth transcending notions of 'culture' and 'nature': emancipative discourses of place for cultural sustainability', Current Opinion in Environmental Sustainability, 43, pp. 58-64. doi: 10.1016/j. cosust.2020.02.003.

Tsing, A. (2007) 'Indigenous voice', in de la Cadena, M. and Starn, O. (eds.) Indigenous experience today. London: Routledge, pp. 33-68.

Virtanen, P. K. (2012) Indigenous youth in Brazilian Amazonia: Changing lived worlds. London: Palgrave.

Wiegel, B., Boas, I. and Warner, J. (2019) 'A mobilities perspective on migration in the context of environmental change', Wiley Interdisciplinary Reviews. Climate Change, 10(6). doi: $10.1002 / \mathrm{wcc} .610$.

Wodak, R. (2015) 'Critical discourse studies: History, agenda, theory and methodology', in Wodak, R. and Meyer, M. (eds.) Methods of critical discourse analysis. 3rd edn. London: Sage, pp. 1-22.

Zickgraf, C. (2019) 'Keeping people in place: Political factors of (im)mobility and climate change'. Social Sciences, 8(8), p. 228. 10.3390/socsci8080228.

\section{Interviews}

008 - Glocal_XX_8female_6.2013.

010 -Glocal_XX_10male_6.2013.

024 - Glocal_XX_24female_6.2013.

041 - D 40: 041_Glocal_XX_RYHMÄ_ATLAS

045 - D 44: 045_Glocal_XX_F_ATLAS 